1. Supplementary Information:

\begin{tabular}{|l|l|l|l|}
\hline Item & Present? & $\begin{array}{l}\text { Filename } \\
\text { This should be the name } \\
\text { the file is saved as when it } \\
\text { is uploaded to our system, } \\
\text { and should include the file } \\
\text { extension. The extension } \\
\text { must be .pdf }\end{array}$ & $\begin{array}{l}\text { A brief, numerical description of file contents. } \\
\text { i.e.: Supplementary Figures 1-4, Supplementary Discussion, and } \\
\text { Supplementary Tables 1-4. }\end{array}$ \\
\hline Supplementary Information & Yes & $\begin{array}{l}\text { Meijaard et al. Oil palm } \\
\text { and biodiversity } \\
\text { (Supporting Information) } \\
\text { - final.pdf }\end{array}$ & Supplementary materials. Figures S1-S2. Table S1-S3. \\
\hline Reporting Summary & No & & \\
\hline
\end{tabular}

\begin{tabular}{|c|c|c|c|}
\hline Type & $\begin{array}{l}\text { Number } \\
\text { If there are multiple files of the same } \\
\text { type this should be the numerical } \\
\text { indicator. i.e. "1" for Video } 1 \text {, "2" for } \\
\text { Video 2, etc. }\end{array}$ & $\begin{array}{l}\text { Filename } \\
\text { This should be the name the file is saved } \\
\text { as when it is uploaded to our system, } \\
\text { and should include the file extension. } \\
\text { i.e.: Smith_ } \\
\text { Supplementary Video 1.mov }\end{array}$ & $\begin{array}{l}\text { Legend or Descriptive Caption } \\
\text { Describe the contents of the file }\end{array}$ \\
\hline Supplementary Table & ( & Table S4.xIxs & $\begin{array}{l}\text { List of species on the IUCN Red List } \\
\text { of Threatened Species for which oil } \\
\text { crops are one of the threats to the }\end{array}$ \\
\hline
\end{tabular}




\begin{tabular}{|l|l|l|l|}
\hline & & & $\begin{array}{l}\text { survival (1=impacted by the crop; } \\
0=\text { not impacted by the crop). }\end{array}$ \\
\hline
\end{tabular}




\section{The environmental impacts of palm oil in 10 context}

11 Erik Meijaard ${ }^{1,2,3^{*}}$, Thomas Brooks ${ }^{4,5,6}$, Kimberly M. Carlson ${ }^{7,8}$, Eleanor M. Slade ${ }^{9}$, John Garcia Ulloa ${ }^{10}$,

12 David L.A. Gaveau ${ }^{11}$, Janice Ser Huay Lee ${ }^{9}$, Truly Santika ${ }^{1,2}$, Diego Juffe-Bignoli ${ }^{2,12}$, Matthew J.

13 Struebig ${ }^{2}$, Serge A. Wich ${ }^{13,14}$, Marc Ancrenaz ${ }^{1,15}$, Lian Pin Koh ${ }^{16}$, Nadine Zamira ${ }^{17}$, Jesse. F. Abrams ${ }^{18,19}$,

14 Herbert H.T. Prins ${ }^{20}$, Cyriaque N. Sendashonga ${ }^{21}$, Daniel Murdiyarso ${ }^{10,22}$, Paul R. Furumo ${ }^{23}$, Nicholas

15 Macfarlane ${ }^{4}$, Rachel Hoffmann ${ }^{24}$, Marcos Persio $^{25}$, Adrià Descals ${ }^{26}$, Zoltan Szantoi ${ }^{27,28}$, Douglas Sheil ${ }^{29}$

$16{ }^{1}$ Borneo Futures, Bandar Seri Begawan, Brunei Darussalam.

$17{ }^{2}$ Durrell Institute of Conservation and Ecology, University of Kent, Canterbury, UK.

$18{ }^{3}$ School of Biological Sciences, University of Queensland, St Lucia, Australia.

$19{ }^{4}$ Science and Knowledge Unit, IUCN, Gland, Switzerland.

$20{ }^{5}$ World Agroforestry Center (ICRAF), University of The Philippines Los Baños, Laguna, Philippines.

$21{ }^{6}$ Institute for Marine \& Antarctic Studies, University of Tasmania, Hobart, Australia.

$22{ }^{7}$ Department of Natural Resources and Environmental Management, the University of Hawai'i at

23 Mānoa, HI, USA.

$24{ }^{8}$ Department of Environmental Studies, New York University, New York, NY, USA.

$25{ }^{9}$ Asian School of the Environment, Nanyang Technological University of Singapore, Singapore.

$26{ }^{10}$ Department of Environmental Systems Science, ETH Zürich, Zürich, Switzerland.

$27{ }^{11}$ Center for International Forestry Research, Bogor, Indonesia. 
$28{ }^{12}$ UN Environment Programme World Conservation Monitoring Centre (UNEP-WCMC), Cambridge,

29 UK.

$30{ }^{13}$ School of Biological and Environmental Sciences, Liverpool John Moores University, Liverpool, UK.

$31{ }^{14}$ Institute for Biodiversity and Ecosystem Dynamics, University of Amsterdam, Amsterdam, The

32 Netherlands.

$33{ }^{15}$ Kinabatangan Orang-Utan Conservation Programme, Kota Kinabalu, Sabah, Malaysia.

$34{ }^{16}$ Department of Biological Sciences, National University of Singapore, Singapore.

$35{ }^{17}$ Rainforest Alliance, Washington, DC, USA.

$36{ }^{18}$ Department of Ecological Dynamics, Leibniz Institute for Zoo and Wildlife Research, Berlin,

37 Germany.

$38{ }^{19}$ Global Systems Institute and Institute for Data Science and Artificial Intelligence, University of 39 Exeter, Exeter, United Kingdom.

$40 \quad{ }^{20}$ Animal Sciences Group, Wageningen University, the Netherlands.

$41 \quad{ }^{21}$ IUCN Policy and Programme Group, IUCN, Gland, Switzerland.

$42 \quad 22$ Department of Geophysics and Meteorology, IPB University, Bogor, Indonesia.

$43 \quad{ }^{23}$ Earth System Science, Stanford University, CA, USA.

$44 \quad{ }^{24}$ Department of Veterinary Medicine, University of Cambridge, UK.

$45 \quad 25$ Instituto de Ciências Biológicas, Universidade Federal do Pará, Belém, Brazil.

$46 \quad{ }^{26}$ Centre de Recerca Ecològica i Aplicacions Forestals, Cerdanyola del Vallès, Barcelona, Spain.

$47 \quad{ }^{27}$ European Commission, Joint Research Centre, Ispra, Italy.

$48 \quad{ }^{28}$ Stellenbosch University, Stellenbosch, South Africa. 
$49{ }^{29}$ Department of Ecology and Natural Resource Management, Norwegian University of Life Sciences, 50 Ås, Norway.

$51 *$ *e-mail: emeijaard@gmail.com

\section{Abstract}

53 Delivering the Sustainable Development Goals (SDGs) requires balancing demands on land between 54 agriculture (SDG 2) and biodiversity (SDG 15). The production of vegetable oils, and in particular 55 palm oil, illustrates these competing demands and trade-offs. Palm oil accounts for $40 \%{ }^{1}$ of the 56 current global annual demand for vegetable oil as food, animal feed, and fuel (210 million tons ${ }^{2}$

$57(\mathrm{Mt}))$, but planted oil palm covers less than $5-5.5 \%^{3}$ of total global oil crop area (ca. $\left.425 \mathrm{Mha}\right)^{4}$, due

58 to oil palm's relatively high yields ${ }^{5}$. Recent oil palm expansion in forested regions of Borneo,

59 Sumatra, and the Malay Peninsula, where $>90 \%$ of global palm oil is produced ${ }^{5}$, has led to substantial 60 concern around oil palm's role in deforestation. Oil palm expansion's direct contribution to regional

61 tropical deforestation varies widely, ranging from $3 \%$ in West Africa to $47 \%$ in Malaysia ${ }^{6}$. Oil palm is

62 also implicated in peatland draining and burning in Southeast Asia. Documented negative

63 environmental impacts from such expansion include biodiversity declines, greenhouse gas

64 emissions, and air pollution. However, oil palm generally produces more oil per area than other oil

$65 \mathrm{crops}^{7}$, is often economically viable in sites unsuitable for most other crops, and generates

66 considerable wealth for at least some actors ${ }^{8}$. Global demand for vegetable oils is projected to

67 increase by $46 \%$ by $2050^{9}$. Meeting this demand through additional expansion of oil palm versus

68 other vegetable oil crops will lead to substantial differential effects on biodiversity, food security,

69 climate change, land degradation, and livelihoods. Our review highlights that, although substantial

70 gaps remain in our understanding of the relationship between the environmental, socio-cultural and

71 economic impacts of oil palm, and the scope, stringency and effectiveness of initiatives to address

72 these, there has been little research into the impacts and trade-offs of other vegetable oil crops. 
73 Greater research attention needs to be given to investigating the impacts of palm oil production

74 compared to alternatives for the trade-offs to be assessed at a global scale.

75 Over the past 25 years, global oil crops have expanded rapidly, with major impacts on land use ${ }^{9}$. The

76 land used for growing oil crops grew from 170 million ha (Mha) in 1961 to 425 Mha in $2017^{4}$ or 30\%

77 of all cropland world-wide ${ }^{10}$. Oil palm, soy, and rapeseed together account for $>80 \%$ of all vegetable

78 oil production with cotton, groundnuts, sunflower, olive, and coconut comprising most of the

79 remainder (Table 1, Figure 1). These crops, including soy (125 Mha planted area ${ }^{4}$ ) and maize (197

80 Mha planted area ${ }^{4}$ ), are also used as animal feed and other products.

81 Oil palm is the most rapidly expanding oil crop. This palm originates from equatorial Africa where it

82 has been cultivated for millennia, but it is now widely grown in Southeast Asia. Between 2008 and

83 2017, oil palm expanded globally at an average rate of 0.7 Mha per year ${ }^{4}$, and palm oil is the leading

84 and cheapest edible oil in much of Asia and Africa. While it has been estimated that palm oil is an

85 ingredient in $43 \%$ of products found in British supermarkets ${ }^{11}$, we lack comparable studies for the

86 prevalence of other oils.

87 As a wild plant, the oil palm is a colonising species that establishes in open areas. Cultivated palms are commonly planted as monocultures, although the tree is also used in mixed, small-scale and agroforestry settings. To maximize photosynthetic capacity and fruit yields, oil palm requires a warm and wet climate, high solar radiation, and high humidity. It is thus most productive in the humid

91 tropics, while other oil crops, except coconut, grow primarily in subtropical and temperate regions

92 (Table 1). Moreover, because oil palm tolerates many soils including deep peat and sandy substrates,

93 it is often profitable in locations where few other commodity crops are viable. The highest yields

94 from planted oil palm have been reported in Southeast Asia ${ }^{5}$. Yields are generally lower in Africa ${ }^{12}$

95 and the Neotropics ${ }^{5}$, likely reflecting differences in climatic conditions including humidity and cloud

96 cover $^{12}$, as well as management, occurrence of pests and diseases, and planting stock ${ }^{13}$. 
97 Palm oil is controversial due to its social and environmental impacts and opportunities. Loss of natural habitats, reduction in woody biomass, and peatland drainage that occur during site preparation are the main direct environmental impacts from oil palm development ${ }^{14}$. Such conversion typically reduces biodiversity and water quality and increases greenhouse gas emissions, and, when fire is used, smoke and haze $e^{5,15}$. Industrial oil palm expansion by large multi-national and national companies is also often associated with social problems, such as land grabbing and conflicts, labour exploitation, social inequity ${ }^{16}$ and declines in village-level well-being ${ }^{17}$. In producer countries, oil palm is a valued crop that brings economic development to regions with few alternative agricultural development options ${ }^{8}$, and generates substantial average livelihood improvements when smallholder farmers adopt oil palm ${ }^{18}$. Here we review the current understanding of the environmental impacts from oil palm cultivation and assess what we know about other oil crops in comparison. Our focus is on biodiversity implications and the environmental aspects of sustainability, and we acknowledge the importance of considering these alongside socio-cultural, political, and economic outcomes.

\section{DEFORESTATION AND OIL PALM EXPANSION}

A remote sensing assessment found that oil palm plantations covered at least 19.5 Mha globally in 2019 (Figure 2), of which an estimated 67.2\% were industrial-scale plantings and the remainder smallholders ${ }^{3}$. With 17.5 Mha, Southeast Asia has the largest area under production, followed by South and Central America (1.31 Mha), Africa (0.58 Mha) and the Pacific (0.14 Mha). However, the actual area under oil palm production could be $10-20 \%$ greater than the area detected from satellite imagery, i.e. 21.5-23.4 Mha, because young plantations (< ca. 3 years), open-canopy plantations, or mixed-species agroforests were omitted ${ }^{3}$. Estimates suggest that the proportion of oil palm area parts of Malaysia and Indonesia ${ }^{17}$ to $94 \%$ in Nigeria ${ }^{5}$. 
121 The overall contribution of oil palm expansion to deforestation varies widely and depends in part on

122 assessment scope (temporal, spatial) and methods. We reviewed 23 studies that reported land use

123 or land cover change involving oil palm (Table S1 and S2). In Malaysian Borneo, oil palm was an

124 important contributor to overall deforestation ${ }^{20}$. Here, new plantations accounted for $50 \%$ of

125 deforestation from 1972 to 2015 when using a 5-year cut-off to link deforestation and oil palm

126 development ${ }^{21}$ (Figure 3, Figure S2, Table S3). In contrast, one global sample-based study suggested

127 that between 2000 and 2013, just $0.2 \%$ of global deforestation in "Intact Forest Landscapes" was

128 caused by oil palm development ${ }^{22}$.

129 The degree to which oil palm expansion has replaced forests (defined as naturally regenerating

130 closed canopy forests) varies with context. From 1972 to 2015 , around $46 \%$ of new plantations

131 expanded into forest, with the remainder replacing croplands, pasturelands, scrublands (including

132 secondary forest regrowth), and other land uses ${ }^{5}$. Individual studies reported forest clearance

133 ranging from $68 \%$ of tracked oil palm expansion in Malaysia and $44 \%$ in the Peruvian Amazon, to just

$1345-6 \%$ in West Africa, Central America, and South America excluding Peru (Figure 3). In general, oil

135 palm expansion in the Neotropics is characterized by the conversion of previously cleared lands

136 instead of forests ${ }^{23,24}$, although the extent to which oil palm displaces other land uses into forests

137 remains uncertain. In Indonesia and Malaysian Borneo, industrial plantation expansion and

138 associated deforestation have declined since ca. $2011^{6,25}$. However, smallholder plantings developed

139 to support demand by industrial palm oil mills may be increasing. To date, only two studies have

140 clearly differentiated between forest clearing by smallholders and industrial plantations (Table S2).

141 In Peru, 30\% of smallholder plantings resulted in deforestation ${ }^{26}$, while in Sumatra, Indonesia 39\% of

142 smallholder expansion was into forest ${ }^{27}$. While we still lack broader understanding of the

143 deforestation impacts of smallholders ${ }^{27}$, recent studies from Indonesian Borneo show that like

144 industrial actors, smallholders sometimes convert fragile ecosystems such as tropical peatlands into 
oil palm plantations ${ }^{28}$. Other oil crops have not yet been mapped globally with similar levels of accuracy, precluding detailed assessments and comparisons.

\section{OIL PALM'S DIRECT IMPACTS ON SPECIES}

148 The International Union for the Conservation of Nature (IUCN) Red List of Threatened Species ${ }^{29}$ documents 321 species for which oil palm is a reported threat, significantly more than for other oil crops (Figure 4, Table 1). Species threatened by oil palm made up 3.5\% of the taxa threatened by annual and perennial non-timber crops $(9,088$ species $)$ and $1.2 \%$ of all globally threatened taxa (27,159 species) in 2019 (Supplementary Materials, Table S4). These species include orangutans Pongo spp., gibbons Hylobates spp. and the tiger Panthera tigris. Species threat lists, however, are incomplete as most plant groups have not been comprehensively assessed, and the focus of threat studies may be biased toward certain oil crops. For example, perennial crops (oil palm, coconut, olive) might be more easily identified as a threat to a species than annual crops, because perennial crops facilitate long-term studies that are more difficult with annual crops that may not be planted every year. Also, the IUCN Red List focuses on threats in the recent past, and is thus biased toward crops with recent rapid expansion. Better information is needed for all oil crops about where they are grown, and how their expansion has affected and could affect natural and semi-natural ecosystems and biodiversity. We note that because coconut is primarily grown in tropical island nations it stands out as a particular threat for rare and endemic species with small ranges ${ }^{30}$ (Table 1 ).

Oil palm plantations contain lower species diversity and abundance for most taxonomic groups when compared to natural forest ${ }^{31,32}$. Plant diversity in some plantations is less than $1 \%$ of that in natural forests ${ }^{31}$, but because oil palm is perennial, associated plant diversity may exceed that of annual oil crops (Table 1). One study found 298 plant species in the oil palm undergrowth ${ }^{33}$, and another found 16 species of fern on oil palm trunks ${ }^{34}$, while a meta-analysis of plant diversity in a range of annual crops, including oil crops, found between one and 15 associated plant species ${ }^{35}$. 
Plant diversity in any oil croplands also depends on management choices such as tillage, weeding and the use of herbicides or other chemicals.

171 Recorded mammal diversity in oil palm is $47-90 \%$ lower than in natural forest ${ }^{36,37}$, and strongly depends on the proximity of natural forests. Oil palm plantations generally exclude forest specialist species ${ }^{38,39}$, which are often those species of greatest conservation importance. For example, forestdependent gibbons (Hylobatidae) cannot survive in stands of monocultural oil palm, but can make use of interspersed forest fragments within an oil palm matrix ${ }^{31}$. Some species, although unable to survive solely in oil palm, will utilise plantations. For instance, planted oil palm in Malaysian Borneo supported 22 of the 63 mammal species found in forest habitats ${ }^{36}$, and 31 of 130 bird species $^{40}$, most of them relatively common species. Oil palm in Guatemala and Brazil supported 23 and 58 bird species, respectively ${ }^{39,41}$, while 12 species of snakes were found in a Nigerian oil palm plantation ${ }^{42}$. Various species will enter plantations to feed on oil palm fruit, including Palm-nut Vultures Gypohierax angolensis ${ }^{43}$ and Chimpanzee Pan troglodytes ${ }^{43}$ in Africa and porcupines (Hystricidae), civets (Viverridae), macaques (Cercopithecidae), elephants (Elephantidae) and orangutans in Southeast Asia ${ }^{44}$. The highest diversity of animal species in oil palm areas, however, is generally found in the wider landscape that includes remnant patches of native vegetation ${ }^{45,46}$. Factors that are likely to positively influence biodiversity values in both industrial-scale and smallholder plantations include higher landscape heterogeneity, the presence of large forest patches and connectivity among these ${ }^{47}$, and the plant diversity and structure of undergrowth vegetation. For example, in palm areas where there is systematic cattle grazing, bird and dung beetle abundance and diversity increase ${ }^{48,49}$.

Oil palm cultivation involves the introduction and spread of invasive species including the oil palm itself (noted in Madagascar and Brazil's Atlantic Forests ${ }^{50}$ ), as well as non-native cover crops and nitrogen-fixing plants (e.g., Mucuna bracteata or Calopogonium caeruleum). Similarly, management of oil palm plantations can increase the local abundance of species such as Barn Owls Tyto alba, 
194 introduced into plantations to control rodents ${ }^{51}$. Oil palm plantations also support pests such as the 195 Black Rat Rattus rattus, pigs Sus spp., and beetles such as the Asiatic Rhinoceros Beetle Oryctes 196 rhinoceros and the Red Palm Weevil Rhynchophorus ferrugineus ${ }^{52}$. Such species can impact palm oil production negatively, for example in reducing oil palm yields through damage to the palm or fruit predation $^{53}$. They also have a range of local effects, both positive and negative for biodiversity, including animals that prey on them, such as snakes, owls, monkeys and cats ${ }^{54}$, while the extra food provided by oil palm fruits can increase pig populations resulting in reduced seedling recruitment in forests neighbouring oil palm ${ }^{55}$

Management within oil palm areas to retain riparian reserves and other set-asides containing natural forest may contribute to pollination and pest control within the plantation, although they may also harbour pests and disease ${ }^{56}$. Studies to date suggest overall limited, or neutral, effects of such set-asides on pest control services, spill over of pest species, or oil palm yield ${ }^{57}$. There are also plenty of unknowns, for example, the African beetle Elaiedobius kamerunicus has been introduced as an effective oil palm pollinator and is now widely naturalised in Southeast Asia and America where it also persists in native vegetation and visits the inflorescences of native palms but its impacts, if any, are unexamined (DS pers. obs.). No systematic analysis has been conducted to assess the impact of non-native and invasive species associated with other oil crops.

Smallholder plantations tend to be smaller and more heterogeneous than industrial developments, which potentially benefits wildlife, but this remains poorly studied ${ }^{32}$. A handful of studies indicate that smallholdings support a similar number of, or slightly more, bird and mammal species than industrial plantations, e.g. ${ }^{58}$. However, species in smallholder plantations may be more exposed to other pressures, such as hunting, when compared to industrial plantations ${ }^{58}$. 
217 Oil palm plantations have a predominantly negative net effect on ecosystem functions when compared to primary, selectively logged or secondary forest ${ }^{15}$. The clearance of forests and drainage of peatlands for oil palm emits substantial carbon dioxide ${ }^{59}$. Oil palms can maintain high rates of carbon uptake $e^{60}$ and their oil can potentially be used to substitute fossil fuels, and thus contribute towards sustainable energy (SDG 7) and climate change response (SDG 13). Yet, biofuel from oil palm cannot compensate for the carbon released when forests are cleared and peatlands drained over short or medium time-scales $(<100 \text { years })^{61}$. Moreover, the carbon opportunity cost of oil palm, which reflects the land's opportunity to store carbon if it is not used for agriculture, is not very different from annual vegetable oil crops ${ }^{61}$ (Table 1).

Oil palm plantations, and the production of palm oil, can also be sources of methane ${ }^{62}$ and nitrous oxide $^{63}$, both potent greenhouse gases that contribute further to climate change, although the former is sometimes used as biogas, reducing net greenhouse gas release ${ }^{64}$. Other emissions associated with oil palm development include elevated isoprene production by palm trees, which influences atmospheric chemistry, cloud cover and rainfall, although how this affects the environment remains unclear ${ }^{65}$. In addition, there is some evidence that emissions of other organic compounds, e.g., estragole and toluene ${ }^{66}$, are also higher in oil palm plantations than in forest, but these emissions appear minor compared to isoprene ${ }^{67}$.

Forest loss and land use conversion to oil palm impact the local and regional climate, although the extent of these impacts remains debated ${ }^{68}$. For example, increased temperatures and reduced rainfall recorded over Borneo since the mid-1970s are thought to relate to the island's declining forest cover which is partly due to the expansion of oil palm, with climate changes being greater in areas where forest losses were higher ${ }^{69}$. Indeed, oil palm plantations tend to be hotter, drier and less shaded than forests due to their less dense canopy, and often have higher evapotranspiration rates than forests ${ }^{70}$. A drier hotter climate increases the risk of fire and concomitant smoke

241 pollution, especially in peat ecosystems ${ }^{71}$. In addition to human health consequences (e.g., 
respiratory diseases, conjunctivitis), such fires can impact wildlife ${ }^{72}$ and atmospheric processes. For example, aerosols from fires can scatter solar radiation, disrupt evaporation, and promote drought ${ }^{68}$.

244 Few of these relationships are well-studied.

245 Conversion of natural forests to oil palm plantations increases run-off and sediment export due to 246 loss or reduction of riparian buffers, reduced ground cover, and dense road networks ${ }^{73}$. Streams

247 flowing through plantations tend to be warmer, shallower, sandier, more turbid, and to have 248 reduced abundances of aquatic species such as dragonflies (Anisoptera) than streams in forested $249 \operatorname{areas}^{74}$. Fertilizers, pesticides, and other chemicals used on plantations also impact water quality and 250 aquatic habitats ${ }^{75}$. The effluent from most modern mills is minimized, but release into local rivers 251 has caused negative impacts to people and to aquatic and marine ecosystems ${ }^{76}$. Some hydrological 252 impacts may be viewed as positive: for example, construction of flood-control channels and 253 sedimentation ponds for palm oil effluent can benefit some water birds ${ }^{77}$.

Drainage of peatlands and other wetlands to establish oil palm disrupts hydrological cycles, 255 potentially impacting neighbouring forests and other habitats ${ }^{78}$. The protection and restoration of riparian buffers and reserves within oil palm plantations is therefore key to preserving water quality, with recent research also showing the importance of these landscape features for biodiversity and ecosystem function ${ }^{79}$. Riparian reserve widths required by law in many tropical countries (20-50 m on each bank) can support substantial levels of biodiversity, maintain hydrological functioning, and improve habitat connectivity and permeability for some species within oil palm ${ }^{79}$. However, research is urgently needed regarding minimum buffer width and size requirements under different contexts, for different taxa, and for different oil crops.

264 Demand for agricultural commodities is growing. Some predict that palm oil production will 265 accelerate across tropical Africa ${ }^{80}$. However, due to current socio-cultural, technical, political and 
ecological constraints only around one-tenth of the potential 51 million ha in the five main

267 producing countries in tropical Africa is likely to be profitably developed in the near future ${ }^{13}$, although this might change as technological, financial and governance conditions improve ${ }^{81}$. The expansion of oil palm in the Neotropics is also uncertain because of greater challenges the sector faces compared to Southeast Asia, including lower yields, high labour costs, volatile socio-political contexts, and high investment costs ${ }^{5}$. Although the importance of these factors varies from country to country, in general the expansion of the palm oil industry in the Americas depends heavily on economic incentives and policies, and access to international markets.

Meeting the growing demand for palm oil, while adhering to new zero deforestation policies ${ }^{82}$, and consumer pressure to be more sustainable, will likely require a combination of approaches, including increasing yields in existing production areas especially those managed by smallholders ${ }^{9}$, and planting in deforested areas and degraded open ecosystems such as man-made pastures ${ }^{60}$. These strategies span a land-sparing and land-sharing continuum, with higher-yielding oil palm cultivation sparing land and perhaps reducing overall impacts on biodiversity ${ }^{38}$, although intermediate strategies on the sparing-sharing continuum may be better at meeting broader societal goals ${ }^{83}$. Irrespective of the optimal strategy, replanting with high-yielding palms or implementing land sharing agroforestry techniques are challenging for smallholders, who often lack resources and technical knowledge, and may not be able to access improved varieties required to increase yields ${ }^{84}$. In such situations, provision of technical support from government agencies, non-government organisations or private companies may help smallholders choose intensification over clearing more land to increase palm oil production ${ }^{12}$.

The extent to which biofuel demand by international markets will drive oil palm expansion remains 
related to the high $\mathrm{CO}_{2}$-emissions from oil palm-driven deforestation and associated peatland development ${ }^{85}$. Nonetheless, if oil palm is developed on low carbon stock lands, estimates suggest it may have lower carbon emissions per unit of energy produced than other oil crops like European rapeseed ${ }^{86}$. Consistent and comparable information on the extent and consequences of other oil crops is urgently required to encourage more efficient land use ${ }^{61}$.

\section{GOVERNANCE OPTIONS}

Efforts to address the impacts of oil palm cultivation and palm oil trade have been the focus of several initiatives. For example, the two main producer countries have set up the Malaysian Sustainable Palm Oil and Indonesian Sustainable Palm Oil certification schemes, which mandate that oil palm producers comply with a set of practices meant to ensure social and environmentally responsible production. International concerns related to deforestation have been addressed through the High Carbon Stock and High Conservation Value approaches ${ }^{87}$, which are methodologies that guide identification and protection of lands with relatively intact forest or value for biodiversity, ecosystem services, livelihoods and cultural identity. These frameworks are used by producers to meet the requirements of palm oil sustainability initiatives including certification under the Roundtable on Sustainable Palm Oil (RSPO) standard. This standard was recently expanded to include protection, management, and restoration of riparian areas within certified plantations, a prohibition on new planting on peat, and compliance with the standard is now being used to meet corporate zero-deforestation commitments ${ }^{5}$. There is evidence for positive impacts of RSPO certification achieved through improved management practices, including changes in agrochemical use, improved forest protection, and reduced fires and biodiversity losses, although these effects remain small ${ }^{88,89}$.

Many producers and traders of palm oil have now committed to "zero deforestation". A 2017 crosscommodity survey ${ }^{90}$ found that companies in the palm oil sector have the highest proportion of no- 
deforestation commitments across four commodity supply chains (palm oil, soy, timber and cattle) linked to global deforestation. Although most of these commitments have been made by retailers and manufacturers ${ }^{90}$, oil palm growers have also made such pledges. In 2018,41 of the 50 palm oil producers with the largest market capitalization and land areas had committed to address deforestation, with 29 of them pledging to adhere to zero deforestation practices ${ }^{91}$. These commitments have been identified as a factor in declining expansion of oil palm in Malaysia and Indonesia ${ }^{6,25}$, although low commodity prices have likely also contributed ${ }^{6}$. Such private supply chain initiatives like certification and zero-deforestation commitments may be most effective in reducing environmental impacts when leveraged with public and institutional support such as plantation moratoria for certain areas and national low-carbon rural development strategies ${ }^{92}$, as has been demonstrated, for example, in Brazilian soy production ${ }^{93}$.

\section{LAND USE TRADE-OFFS AMONG VEGETABLE OILS}

While the environmental impacts of oil palm on natural ecosystems are overwhelmingly negative, such impacts also need to be considered in relation to other land uses, including competing vegetable oil commodities, all of which have their own implications for biodiversity, carbon emissions and other environmental dynamics (Table 1). Global vegetable oil production is expected to expand at around $1.5 \%$ per year between 2017 and $2027^{94}$, while use is projected to expand at 1.7\% per year globally between 2013 and 2050 from a baseline of 165 million tons (Mt), including for use in food, feed and biofuel ${ }^{9}$. Unless demand for oil decelerates, this implies an additional production of an average of $3.86 \mathrm{Mt}$ of vegetable oil per year. If this production was delivered by oil palm alone, yielding ca. 4 tons of crude palm oil per ha, $a^{5,7}, 31.3 \mathrm{Mha}$ of additional vegetable oil production land would be needed between 2020 and 2050. If, the addition instead all came from soy, yielding about 0.7 tons of oil per ha ${ }^{9}, 179$ Mha of extra land, or nearly six times as much, would be required. This simple calculation glosses over nuances of substitutability ${ }^{95}$ or differential yield 
increases among crops, but illustrates the magnitude of differences between land needed by oil

340 palm and other oil crops ${ }^{96}$.

341 Understanding impacts is, however, not just a matter of comparing current and projected

342 distributions and yields of different crops and thus land needs, but also requires clarifying how each

343 hectare of land converted to an oil crop impacts both the environment and people. For example, soy

344 is known to have a large negative impact on biodiversity, with few vertebrates occurring in this

345 annual monoculture crop $^{97}$, and is responsible for loss of high biodiversity savanna and forest

346 ecosystems in South America ${ }^{98}$. Thus, sustainable development, including simultaneous delivery of

347 SDGs 2 on agriculture and 15 on biodiversity (alongside contributions to SDG 7 on energy and SDG

34813 on climate), must consider the wider trade-offs posed by sourcing global vegetable oils ${ }^{99}$. One key

349 uncertainty is the extent to which demand can be met by increasing yields within established

350 vegetable oil croplands. An additional uncertainty is whether other options, for example microalgal-

351 derived lipids ${ }^{100}$, may soon offer viable alternatives to meet demand for biofuel.

\section{THE WAY FORWARD}

353 The expansion of oil palm has had large negative environmental impacts and continues to cause 354 deforestation in some regions. Nevertheless, oil palm contributes to economic development ${ }^{5}$, has 355 improved welfare for at least some people ${ }^{17}$, and can be consistent with at least some conservation 356 goals especially when compared to other oil crops ${ }^{81}$. There remain substantial gaps in our 357 understanding of oil palm and the interaction between environmental, socio-cultural and economic impacts of the crop, and the scope, stringency and effectiveness of governance initiatives to address these $e^{5}$. None of these concerns and trade-offs are unique to oil palm: they also apply to other vegetable oil crops ${ }^{30,98}$, as well as other agricultural products ${ }^{101}$. Indeed, all land uses and not just those in the tropics have impacts on their environment ${ }^{8}$, that can either be prevented or restored ${ }^{102}$. 
of palm oil production compared to other oils resulting in an urgent need to better study these

alternatives.

In a world with finite land and growing demands, we must consider global demands for food, fuel

and industrial uses hand-in-hand with environmental conservation objectives. Oil palm's high yields

mean that it requires less land to meet global oil demand than other oil crops. However, minimising

overall vegetable oil crop impacts requires evaluation for their past, current and projected

distribution and impacts, and review of their yields and global trade and uses. This information is

SDGs.

USDA. Oil Seeds: World Markets and Trade. November 2019. (Foreign Agricultural Service, United States Department of Agriculture, Washington, DC, 2019).

2 USDA-FAS. Oilseeds: World Markets and Trade. Circular Series FOP 8-10 August. (United States Department of Agriculture Foreign Agricultural Service, Washington, DC, 2010).

3 Descals, A. et al. High-resolution global map of smallholder and industrial closed-canopy oil palm plantations. Preprint at https://essd.copernicus.org/preprints/essd-2020-159/. doi:10.5194/essd-2020-159 (2020).

4 FAOSTAT. Food and Agriculture Data. http://www.fao.org/faostat/en/\#home. (Food and Agriculture Organization of the United Nations, Rome, Italy, 2019).

5 Meijaard, E. et al. Oil Palm and Biodiversity - A Situation Analysis. DOI: 10.2305/IUCN.CH.2018.11.en. (IUCN Oil Palm Task Force, 2018).

6 Gaveau, D. L. A. et al. Rise and fall of forest loss and industrial plantations in Borneo (20002017). Cons. Lett. 0, e12622, doi:10.1111/conl.12622 (2019).

7 Johnston, M., Foley, J. A., Holloway, T., Kucharik, C. \& Monfreda, C. Resetting global expectations from agricultural biofuels. Env. Res. Lett. 4, 014004, doi:10.1088/17489326/4/1/014004 (2009).

8 Meijaard, E. \& Sheil, D. The Moral Minefield of Ethical Oil Palm and Sustainable Development. Front. Forests Glob. Change 2, doi:10.3389/ffgc.2019.00022 (2019).

9 Byerlee, D., Falcon, W. P. \& Naylor, R. L. The Tropical Oil Crop Revolution: Food, Feed, Fuel, and Forests. (Oxford University Press, 2017).

10 Ramankutty, N. et al. Trends in Global Agricultural Land Use: Implications for Environmental Health and Food Security. Ann. Rev. Plant Biol. 69, 789-815, doi:10.1146/annurev-arplant042817-040256 (2018).

11 Independent. The guilty secrets of palm oil: Are you unwittingly contributing to the devastation of the rain forests?. https://www.independent.co.uk/environment/the-guilty- 


\section{8.html. (2009).}

12 Woittiez, L. S., van Wijk, M. T., Slingerland, M., van Noordwijk, M. \& Giller, K. E. Yield gaps in oil palm: A quantitative review of contributing factors. Europ. J. Agron. 83, 57-77, doi:10.1016/j.eja.2016.11.002 (2017).

13 Feintrenie, L., Gazull, L., Goulaouic, R. \& Miaro III, L. Spatialized production models for sustainable palm oil in Central Africa: Choices and potentials. Presented at Scaling Up Responsible Land Governance. Annual World Bank Conference on Land and Poverty, Washington DC, March 14-18, 2016. (2016).

14 Sheil, D. et al. The impacts and opportunities of oil palm in Southeast Asia. What do we know and what do we need to know? CIFOR Occ. Paper, no. 51 (2009).

15 Dislich, C. et al. A review of the ecosystem functions in oil palm plantations, using forests as a reference system. Biol. Rev. 92, 1539-1569, doi:10.1111/brv.12295 (2017).

$16 \mathrm{Li}, \mathrm{T} ., \mathrm{M}$. Evidence-based options for advancing social equity in Indonesian palm oil: Implications for research, policy and advocacy. (Center for International Forestry Research (CIFOR), 2018).

17 Santika, T. et al. Does oil palm agriculture help alleviate poverty? A multidimensional counterfactual assessment of oil palm development in Indonesia. World Dev. 120, 105-117, doi:10.1016/j.worlddev.2019.04.012 (2019).

18 Krishna, V., Euler, M., Siregar, H. \& Qaim, M. Differential livelihood impacts of oil palm expansion in Indonesia. Agric. Econ. 48, 639-653, doi:10.1111/agec.12363 (2017).

19 RSPO Smallholders Task Force. Smallholders. Retrieved from https://rspo.org/smallholders\#definition. (2012).

20 Gaveau, D. L. A. et al. Four decades of forest persistence, loss and logging on Borneo. PLOS ONE 9, e101654, doi:10.1371/journal.pone.0101654 (2014).

21 Gaveau, D. L. A. et al. Rapid conversions and avoided deforestation: examining four decades of industrial plantation expansion in Borneo. Sci. Rep. 6, 32017, doi:10.1038/srep32017 (2016).

22 Potapov, P. et al. The last frontiers of wilderness: Tracking loss of intact forest landscapes from 2000 to 2013. Sc. Adv. 3, e1600821, doi:10.1126/sciadv.1600821 (2017).

23 Vijay, V., Pimm, S. L., Jenkins, C. N. \& Smith, S. J. The Impacts of Oil Palm on Recent Deforestation and Biodiversity Loss. PLOS ONE 11, e0159668, doi:10.1371/journal.pone.0159668 (2016).

24 Furumo, P. R. \& Aide, T. M. Characterizing commercial oil palm expansion in Latin America: land use change and trade. Env. Res. Lett. 12, 024008, doi:10.1088/1748-9326/aa5892 (2017).

25 Austin, K. G., Schwantes, A., Gu, Y. \& Kasibhatla, P. S. What causes deforestation in Indonesia? Env. Res. Lett. 14, 024007, doi:10.1088/1748-9326/aaf6db (2019).

26 Gutiérrez-Vélez, V., H. et al. High-yield oil palm expansion spares land at the expense of forests in the Peruvian Amazon. Env. Res. Lett. 6, 044029, doi:10.1088/17489326/6/4/044029 (2011).

27 Lee, J. S. H. et al. Environmental Impacts of Large-Scale Oil Palm Enterprises Exceed that of Smallholdings in Indonesia. Cons. Lett. 7, 25-33, doi:10.1111/conl.12039 (2014).

28 Schoneveld, G. C., Ekowati, D., Andrianto, A. \& van der Haar, S. Modeling peat- and forestland conversion by oil palm smallholders in Indonesian Borneo. Env. Res. Lett. 14, 014006, doi:10.1088/1748-9326/aaf044 (2019).

29 IUCN. The IUCN Red List of Threatened Species. Version 2019-2. https://www.iucnredlist.org. (Gland, Switzerland, 2019). 


\begin{tabular}{|c|c|c|}
\hline 447 & 30 & $\begin{array}{l}\text { Meijaard, E., Abrams, J. F., Juffe-Bignoli, D., Voigt, M. \& Sheil, D. Coconut oil, conservation } \\
\text { and the conscientious consumer. Curr. Biol. 30, R757-R758, doi:10.1016/j.cub.2020.05.059 } \\
\text { (2020). }\end{array}$ \\
\hline 450 & 31 & \\
\hline 451 & & cosvetem function in the oil nalm landscanes of South Fact $\Delta$ cia Phil Tranc Rov Soc $R$. \\
\hline 452 & & Sc. 366, 3277, doi:10.1098/rstb.2011.0041 (2011). \\
\hline $\begin{array}{l}453 \\
454\end{array}$ & 32 & $\begin{array}{l}\text { Savilaakso, S. et al. Systematic review of effects on biodiversity from oil palm production. } \\
\text { Env. Evidence } 3 \text {. 4oi:10.1186/2047-2382-3-4 (2014). }\end{array}$ \\
\hline 455 & 33 & Germer, J. U. Spatial undergrowth species composition in oil palm (Elaeis guineensis Jacq.) in \\
\hline $\begin{array}{l}456 \\
457\end{array}$ & & $\begin{array}{l}\text { West Sumatra, Kommunikations-, Informations- und Medienzentrum der Universität } \\
\text { Hohenheim, (2003). }\end{array}$ \\
\hline $\begin{array}{l}458 \\
459 \\
460\end{array}$ & 34 & $\begin{array}{l}\text { Sato, T., Itoh, H., Kudo, G., Kheong, Y. S. \& Furukawa, A. Species Composition and Structure } \\
\text { of Epiphytic Fern Community on Oil Palm Trunks in Malay Archipelago. Tropics 6, 139-148, } \\
\text { doi:10.3759/tropics.6.139 (1996). }\end{array}$ \\
\hline $\begin{array}{l}461 \\
462\end{array}$ & 35 & $\begin{array}{l}\text { Letourneau, D. K. et al. Does plant diversity benefit agroecosystems? A synthetic review. } \\
\text { Ecol. Appl. 21, 9-21, doi:10.1890/09-2026.1 (2011). }\end{array}$ \\
\hline $\begin{array}{l}463 \\
464 \\
465\end{array}$ & 36 & $\begin{array}{l}\text { Wearn, O. R., Carbone, C., Rowcliffe, J. M., Bernard, H. \& Ewers, R. M. Grain-dependent } \\
\text { responses of mammalian diversity to land use and the implications for conservation set- } \\
\text { aside. Ecol. Appl. 26, 1409-1420, doi:10.1890/15-1363 (2016). }\end{array}$ \\
\hline $\begin{array}{l}466 \\
467 \\
468\end{array}$ & 37 & $\begin{array}{l}\text { Pardo, L. E. et al. Land management strategies can increase oil palm plantation use by some } \\
\text { terrestrial mammals in Colombia. Scient. Rep. 9, 7812, doi:10.1038/s41598-019-44288-y } \\
\text { (2019). }\end{array}$ \\
\hline $\begin{array}{l}469 \\
470 \\
471\end{array}$ & 38 & $\begin{array}{l}\text { Phalan, B., Onial, M., Balmford, A. \& Green, R. E. Reconciling Food Production and } \\
\text { Biodiversity Conservation: Land Sharing and Land Sparing Compared. Science 333, 1289- } \\
\text { 1291 doi:10.1126/science } 1208742 \text { (2011) }\end{array}$ \\
\hline $\begin{array}{l}471 \\
472 \\
473\end{array}$ & 39 & $\begin{array}{l}\text { loi:10.1126/science. } 1208742(2011) \text {. } \\
\text { a, S. M. et al. The effects of oil palm plantations on the functional diversity of } \\
\text { nian birds. J. Trop. Ecol. 32,510-525, doi:10.1017/S0266467416000377 (2016). }\end{array}$ \\
\hline $\begin{array}{l}474 \\
475 \\
476\end{array}$ & 40 & $\begin{array}{l}\text { Edwards, D. P. et al. Selective-logging and oil palm: multitaxon impacts, biodiversity } \\
\text { indicators, and trade-offs for conservation planning. Ecol. Applic. 24, 2029-2049, } \\
\text { doi:10.1890/14-0010.1 (2014). }\end{array}$ \\
\hline $\begin{array}{l}477 \\
478\end{array}$ & 41 & $\begin{array}{l}\text { Nájera, A. \& Simonetti, J. A. Can oil palm plantations become bird friendly? Agrofor. Syst. 80, } \\
\text { 203-209, doi:10.1007/s10457-010-9278-y (2010). }\end{array}$ \\
\hline $\begin{array}{l}479 \\
480 \\
481\end{array}$ & 42 & $\begin{array}{l}\text { Akani, G. C., Ebere, N., Luiselli, L. \& Eniang, E. A. Community structure and ecology of snakes } \\
\text { in fields of oil palm trees (Elaeis guineensis) in the Niger Delta, southern Nigeria. Afr. J. Ecol. } \\
\text { 46.500-506, doi:10.1111/i.1365-2028.2007.00885. }(2008) \text {. }\end{array}$ \\
\hline $\begin{array}{l}481 \\
482\end{array}$ & 43 & $\begin{array}{l}\text { 46, 500-506, doi:10.1111/j.1365-2028.2007.00885.x (2008). } \\
\text { Humle, T. \& Matsuzawa, T. Oil palm use by adjacent communities of chimpanzees at Bossou }\end{array}$ \\
\hline $\begin{array}{l}483 \\
484\end{array}$ & & $\begin{array}{l}\text { and Nimba Mountains, West Africa. Int. J. Primatol. 25, 551-581, } \\
\text { doi:10.1023/B:IJOP.0000023575.93644.f4 (2004). }\end{array}$ \\
\hline $\begin{array}{l}485 \\
486 \\
487\end{array}$ & 44 & $\begin{array}{l}\text { Ancrenaz, M. et al. Of pongo, palms, and perceptions - A multidisciplinary assessment of } \\
\text { orangutans in an oil palm context. Oryx 49,465-472, doi:10.1017/S0030605313001270 } \\
\text { (2015). }\end{array}$ \\
\hline $\begin{array}{l}488 \\
489\end{array}$ & 45 & $\begin{array}{l}\text { Mitchell, S. L. et al. Riparian reserves help protect forest bird communities in oil palm } \\
\text { dominated landscapes. J. Appl. Ecol. 55, 2744-2755, doi:10.1111/1365-2664.13233 (2018). }\end{array}$ \\
\hline $\begin{array}{l}490 \\
491 \\
492\end{array}$ & 46 & $\begin{array}{l}\text { Deere, N. J. et al. Implications of zero-deforestation commitments: Forest quality and } \\
\text { hunting pressure limit mammal persistence in fragmented tropical landscapes. Cons. Lett. } \\
\text { 13. e12701, doi:10.1111/conl.12701 (2020). }\end{array}$ \\
\hline $\begin{array}{l}493 \\
494 \\
495\end{array}$ & 47 & $\begin{array}{l}\text { Knowlton, J. L. et al. Oil palm plantations affect movement behavior of a key member of } \\
\text { mixed-species flocks of forest birds in Amazonia, Brazil. Trop. Cons. Sc. 10, } \\
1940082917692800 \text {, doi:10.1177/1940082917692800 (2017). }\end{array}$ \\
\hline
\end{tabular}




\begin{tabular}{|c|c|c|}
\hline 496 & 48 & $\begin{array}{l}\text { ohiran, K. A. et al. Targeted cattle grazing as an alternative to herbicides for controlling } \\
\text { eeds in bird-friendly oil palm plantations. Agron. Sust. Dev. 37, 62, doi:10.1007/s13593- } \\
17-0471-5 \text { (2017). }\end{array}$ \\
\hline $\begin{array}{l}499 \\
500\end{array}$ & 49 & $\begin{array}{l}\text { lade, E. M. et al. Can cattle grazing in mature oil palm increase biodiversity and ecosystem } \\
\text { ervice provision?. The Planter } 90,655-665 \text { (2014). }\end{array}$ \\
\hline $\begin{array}{l}501 \\
502\end{array}$ & 50 & $\begin{array}{l}\text { UCN. Global Invasive Species Database (GISD). Species profile Elaeis guineensis. Available } \\
\text { rom: http://www.iucngisd.org/gisd/species. [Accessed } 27 \text { February 2018]. (2015). }\end{array}$ \\
\hline $\begin{array}{l}503 \\
504\end{array}$ & 51 & $\begin{array}{l}\text { Nan, H. The introduction of barn owl (Tyto } a l b a \text { ) to Sabah for rat control in oil palm } \\
\text { lantations. Planter 76, 215-222 (2000). }\end{array}$ \\
\hline $\begin{array}{l}505 \\
506\end{array}$ & 52 & $\begin{array}{l}\text { essou, C. et al. Sustainable Palm Oil Production project synthesis: Understanding and } \\
\text { nticipating global challenges. (Center for International Forestry Research (CIFOR), 2017). }\end{array}$ \\
\hline $\begin{array}{l}507 \\
508 \\
509\end{array}$ & 53 & $\begin{array}{l}\text { Puan, C. L., Goldizen, A. W., Zakaria, M., Hafidzi, M. N. \& Baxter, G. S. Relationships among } \\
\text { rat numbers, abundance of oil palm fruit and damage levels to fruit in an oil palm plantation. } \\
\text { Intergr. Zool. 6, 130-139, doi:10.1111/j.1749-4877.2010.00231.x (2011). }\end{array}$ \\
\hline $\begin{array}{l}510 \\
511 \\
512\end{array}$ & 54 & $\begin{array}{l}\text { Holzner, A. et al. Macaques can contribute to greener practices in oil palm plantations when } \\
\text { used as biological pest control. Curr. Biol. 29, R1066-R1067, doi:10.1016/j.cub.2019.09.011 } \\
\text { (2019). }\end{array}$ \\
\hline $\begin{array}{l}513 \\
514\end{array}$ & 55 & $\begin{array}{l}\text { uskin, M. S. et al. Cross-boundary subsidy cascades from oil palm degrade distant tropical } \\
\text { orests. Nature Comms. 8, 2231, doi:10.1038/s41467-017-01920-7 (2017). }\end{array}$ \\
\hline $\begin{array}{l}515 \\
516 \\
517\end{array}$ & 56 & $\begin{array}{l}\text { Mayfield, M. M. The importance of nearby forest to known and potential pollinators of oil } \\
\text { palm (Elaeis guineensis Jacq.; Areceaceae) in southern Costa Rica. Econ. Botany 59, 190, } \\
\text { doi:10.1663/0013-0001(2005)059[0190:TIONFT]2 (2005). }\end{array}$ \\
\hline $\begin{array}{l}518 \\
519 \\
520\end{array}$ & 57 & $\begin{array}{l}\text { Woodham, C. R. et al. Effects of replanting and retention of mature oil palm riparian buffers } \\
\text { on ecosystem functioning in oil palm plantations. Front. Forests Glob. Change, } \\
\text { doi:10.3389/ffgc.2019.00029(2019). }\end{array}$ \\
\hline $\begin{array}{l}521 \\
522 \\
523\end{array}$ & 58 & $\begin{array}{l}\text { Azhar, B. et al. The influence of agricultural system, stand structural complexity and } \\
\text { landscape context on foraging birds in oil palm landscapes. Ibis 155, 297-312, } \\
\text { doi:10.1111/ibi.12025 (2013). }\end{array}$ \\
\hline $\begin{array}{l}524 \\
525 \\
526\end{array}$ & 59 & $\begin{array}{l}\text { Wijedasa, L. S. et al. Denial of long-term issues with agriculture on tropical peatlands will } \\
\text { have devastating consequences. Glob. Change Biol. 23, 977-982, doi:10.1111/gcb.13516 } \\
\text { (2016). }\end{array}$ \\
\hline $\begin{array}{l}527 \\
528 \\
529\end{array}$ & 60 & $\begin{array}{l}\text { Quezada, J. C., Etter, A., Ghazoul, J., Buttler, A. \& Guillaume, T. Carbon neutral expansion of } \\
\text { oil palm plantations in the Neotropics. Sc. Advan. 5, eaaw4418, doi:10.1126/sciadv.aaw4418 } \\
\text { (2019). }\end{array}$ \\
\hline $\begin{array}{l}530 \\
531 \\
532\end{array}$ & 61 & $\begin{array}{l}\text { Searchinger, T. D., Wirsenius, S., Beringer, T. \& Dumas, P. Assessing the efficiency of changes } \\
\text { in land use for mitigating climate change. Nature 564, 249-253, doi:10.1038/s41586-018- } \\
0757-z \text { (2018). }\end{array}$ \\
\hline $\begin{array}{l}533 \\
534\end{array}$ & 62 & $\begin{array}{l}\text { Reijnders, L. \& Huijbregts, M. A. J. Palm oil and the emission of carbon-based greenhouse } \\
\text { gases. J. Cleaner Prod. 16, 477-482, doi:10.1016/j.jclepro.2006.07.054 (2006). }\end{array}$ \\
\hline $\begin{array}{l}535 \\
536 \\
537\end{array}$ & 63 & $\begin{array}{l}\text { Murdiyarso, D., Van Noordwijk, M., Wasrin, U. R., Tomich, T. P. \& Gillison, A. N. } \\
\text { Environmental benefits and sustainable land-use options in the Jambi transect, Sumatra. J. } \\
\text { Veget. Sc. 13, 429-438, doi:10.1111/j.1654-1103.2002.tb02067.x (2002). }\end{array}$ \\
\hline $\begin{array}{l}538 \\
539 \\
540 \\
541\end{array}$ & 64 & $\begin{array}{l}\text { Harsono, S. S., Grundmann, P. \& Soebronto, S. Anaerobic treatment of palm oil mill } \\
\text { effluents: potential contribution to net energy yield and reduction of greenhouse gas } \\
\text { emissions from biodiesel production. J. Cleaner Prod. 64, 619-627, } \\
\text { doi:10.1016/j.jclepro.2013.07.056 (2014). }\end{array}$ \\
\hline $\begin{array}{l}542 \\
543 \\
544\end{array}$ & 65 & $\begin{array}{l}\text { Hewitt, C. N. et al. Nitrogen management is essential to prevent tropical oil palm plantations } \\
\text { from causing ground-level ozone pollution. Proc. Natl. Acad. Sc. USA 106, 18447, } \\
\text { doi:10.1073/pnas.0907541106 (2009). }\end{array}$ \\
\hline
\end{tabular}




\begin{tabular}{|c|c|c|}
\hline $\begin{array}{l}545 \\
546\end{array}$ & 66 & $\begin{array}{l}\text { Misztal, P. K. et al. Direct ecosystem fluxes of volatile organic compounds from oil palms in } \\
\text { outh-East Asia. Atmos. Chem. Phys. 11, 8995-9017, doi:10.5194/acp-11-8995-2011 (2011). }\end{array}$ \\
\hline 547 & 67 & Guenther, A. et al. The Model of Emissions of Gases and Aerosols from Nature version 2.1 \\
\hline 548 & & (MEGAN2. 1): an extended and updated framework for modeling biogenic emissions. \\
\hline 49 & & \\
\hline $\begin{array}{l}550 \\
551\end{array}$ & 68 & $\begin{array}{l}\text { Ellison, D. et al. Trees, forests and water: Cool insights for a hot world. Glob. Env. Change 43, } \\
\text { 51-61, doi:10.1016/j.gloenvcha.2017.01.002 (2017). }\end{array}$ \\
\hline $\begin{array}{l}552 \\
553\end{array}$ & 69 & $\begin{array}{l}\text { McAlpine, C. A. et al. Forest loss and Borneo's climate. Env. Res. Lett. 13, 044009, } \\
\text { doi:10.1088/1748-9326/aaa4ff (2018). }\end{array}$ \\
\hline 554 & 70 & $\begin{array}{l}\text { Fan, Y. et al. Reconciling canopy interception parameterization and rainfall forcing frequency } \\
\text { in the community land model for simulating evapotranspiration of rainforests and oil palm }\end{array}$ \\
\hline $\begin{array}{l}556 \\
557\end{array}$ & & $\begin{array}{l}\text { plantations in Indonesia. J. Advan. Model. Earth Syst. 11, 732-751, } \\
\text { doi:10.1029/2018MS001490(2019). }\end{array}$ \\
\hline $\begin{array}{l}558 \\
559\end{array}$ & 71 & $\begin{array}{l}\text { Crippa, P. et al. Population exposure to hazardous air quality due to the } 2015 \text { fires in } \\
\text { Equatorial Asia. Sci. Rep. 6, 37074, doi:10.1038/srep37074 (2016). }\end{array}$ \\
\hline $\begin{array}{l}560 \\
561\end{array}$ & 72 & $\begin{array}{l}\text { Nichol, J. Bioclimatic impacts of the } 1994 \text { smoke haze event in Southeast Asia. Atmosph. Env. } \\
\text { 31, 1209-1219, doi:10.1016/S1352-2310(96)00260-9 (1997). }\end{array}$ \\
\hline $\begin{array}{l}562 \\
563 \\
564\end{array}$ & 73 & $\begin{array}{l}\text { Carlson, K. M. et al. Consistent results in stream hydrology across multiple watersheds: A } \\
\text { reply to Chew and Goh. J. Geophys. Res. Biogeosci. 120, 812-817, } \\
\text { doi:10.1002/2014JG002834 (2015). }\end{array}$ \\
\hline $\begin{array}{l}565 \\
566 \\
567\end{array}$ & 74 & $\begin{array}{l}\text { Luke, S. H. et al. The effects of catchment and riparian forest quality on stream } \\
\text { environmental conditions across a tropical rainforest and oil palm landscape in Malaysian } \\
\text { Borneo. Ecohydrol. 10, e1827, doi:10.1002/eco.1827 (2017). }\end{array}$ \\
\hline $\begin{array}{l}568 \\
569\end{array}$ & 75 & $\begin{array}{l}\text { Mayer, P. M., Reynolds, S. K., McCutchen, M. D. \& Canfield, T. J. Meta-Analysis of Nitrogen } \\
\text { Removal in Riparian Buffers. J. Env. Qual. 36, 1172-1180, doi:10.2134/jeq2006.0462 (2007). }\end{array}$ \\
\hline $\begin{array}{l}570 \\
571 \\
572\end{array}$ & 76 & $\begin{array}{l}\text { Chellaiah, D. \& Yule, C. M. Effect of riparian management on stream morphometry and } \\
\text { water quality in oil palm plantations in Borneo. Limnologica 69, 72-80, } \\
\text { doi:10.1016/j.limno.2017.11.007 (2018). }\end{array}$ \\
\hline $\begin{array}{l}573 \\
574 \\
575\end{array}$ & 77 & $\begin{array}{l}\text { Sulai, P. et al. Effects of water quality in oil palm production landscapes on tropical } \\
\text { waterbirds in Peninsular Malaysia. Ecol. Res. 30, 941-949, doi:10.1007/s11284-015-1297-8 } \\
\text { (2015). }\end{array}$ \\
\hline $\begin{array}{l}576 \\
577 \\
578\end{array}$ & 78 & $\begin{array}{l}\text { Anda, M., Siswanto, A. B. \& Subandiono, R. E. Properties of organic and acid sulfate soils and } \\
\text { water of a 'reclaimed' tidal backswamp in Central Kalimantan, Indonesia. Geoderma 149, } 54- \\
65 \text {, doi:10.1016/j.geoderma.2008.11.021 (2009). }\end{array}$ \\
\hline $\begin{array}{l}579 \\
580\end{array}$ & 79 & $\begin{array}{l}\text { Luke, S. H. et al. Riparian buffers in tropical agriculture: Scientific support, effectiveness and } \\
\text { directions for policy. J. Appl. Ecol. 56, 85-92, doi:10.1111/1365-2664.13280 (2019). }\end{array}$ \\
\hline $\begin{array}{l}581 \\
582\end{array}$ & 80 & $\begin{array}{l}\text { Wich, Serge A. et al. Will Oil Palm's Homecoming Spell Doom for Africa's Great Apes? Curr. } \\
\text { Biol. 24, 1659-1663, doi:10.1016/j.cub.2014.05.077 (2014). }\end{array}$ \\
\hline $\begin{array}{l}583 \\
584 \\
585\end{array}$ & 81 & $\begin{array}{l}\text { Sayer, J., Ghazoul, J., Nelson, P. \& Boedhihartono, A. K. Oil palm expansion transforms } \\
\text { tropical landscapes and livelihoods. Glob. Food Secur. 1, 114-119, } \\
\text { doi:10.1016/j.gfs.2012.10.003 (2012). }\end{array}$ \\
\hline $\begin{array}{l}586 \\
587 \\
588\end{array}$ & 82 & $\begin{array}{l}\text { RSPO. RSPO and HCSA Collaborate to Implement No Deforestation in High Forest Cover } \\
\text { Landscapes. } \\
\text { implement-no-deforestation-in-high-forest-cover-landscapes. (2018). }\end{array}$ \\
\hline $\begin{array}{l}589 \\
590\end{array}$ & 83 & $\begin{array}{l}\text { Law, E. A. et al. Mixed policies give more options in multifunctional tropical forest } \\
\text { landscapes. J. Appl. Ecol. 54, 51-60, doi:10.1111/1365-2664.12666 (2017). }\end{array}$ \\
\hline $\begin{array}{l}591 \\
592\end{array}$ & 84 & $\begin{array}{l}\text { Budiadi et al. Oil palm agroforestry: an alternative to enhance farmers' livelihood resilience. } \\
\text { IOP Conf. Ser.: Earth Env. Sc. 336, 012001, doi:10.1088/1755-1315/336/1/012001 (2019). }\end{array}$ \\
\hline
\end{tabular}


$593 \quad 85 \quad$ Valin, H. et al. The land use change impact of biofuels consumed in the EU. Quantification of 594 area and greenhouse gas impacts. (ECOFYS Netherlands B.V., Utrecht, the Netherlands,

86 Thamsiriroj, T. \& Murphy, J. D. Is it better to import palm oil from Thailand to produce biodiesel in Ireland than to produce biodiesel from indigenous Irish rape seed? Appl. Energy 86, 595-604, doi:10.1016/j.apenergy.2008.07.010 (2009).

87 Rosoman, G., Sheun, S. S., Opal, C., Anderson, P. \& Trapshah, R. The HCS Approach Toolkit. (HCS Approach Steering Group, Singapore, 2017).

88 Carlson, K. M. et al. Effect of oil palm sustainability certification on deforestation and fire in Indonesia. Proc. Natl. Acad. Sci. USA 115, 121-126, doi:10.1073/pnas.1704728114 (2018).

89 Furumo, P. R., Rueda, X., Rodríguez, J. S. \& Parés Ramos, I. K. Field evidence for positive certification outcomes on oil palm smallholder management practices in Colombia. J. Cleaner Prod. 245, 118891, doi:https://doi.org/10.1016/j.jclepro.2019.118891 (2020).

90 Donofrio, S., Rothrock, P. \& Leonard, J. Tracking Corporate Commitments to Deforestationfree Supply Chains, 2017. (Forest Trends, Washington, DC, 2017).

91 SPOTT. Palm oil: ESG policy transparency assessments. https://www.spott.org/palm-oil/. (2018).

92 Furumo, P. R. \& Lambin, E. F. Scaling up zero-deforestation initiatives through public-private partnerships: A look inside post-conflict Colombia. 62, 102055, doi:https://doi.org/10.1016/j.gloenvcha.2020.102055 (2020).

93 Gibbs, H. K. et al. Brazil's Soy Moratorium. Science 347, 377, doi:10.1126/science.aaa0181 (2015).

94 OECD and FAO. OECD?FAO Agricultural Outlook 2018?2027. (2017).

95 Parsons, S., Raikova, S. \& Chuck, C. J. The viability and desirability of replacing palm oil. Nat. Sust. 3, 412-418, doi:10.1038/s41893-020-0487-8 (2020).

96 Qaim, M., Sibhatu, K. T., Siregar, H. \& Grass, I. Environmental, Economic, and Social Consequences of the Oil Palm Boom. Ann. Rev. 12, 321-344, doi:10.1146/annurev-resource110119-024922 (2020).

97 VanBeek, K. R., Brawn, J. D. \& Ward, M. P. Does no-till soybean farming provide any benefits for birds? Agricult. Ecosyst. Env. 185, 59-64, doi:https://doi.org/10.1016/j.agee.2013.12.007 (2014).

98 Green, J. M. H. et al. Linking global drivers of agricultural trade to on-the-ground impacts on biodiversity. Proc. Natl. Acad. Sci. USA 116, 23202, doi:10.1073/pnas.1905618116 (2019).

99 Strona, G. et al. Small room for compromise between oil palm cultivation and primate conservation in Africa. Proc. Natl. Acad. Sci. USA 115, 8811, doi:10.1073/pnas.1804775115 (2018).

100 Ajjawi, I. et al. Lipid production in Nannochloropsis gaditana is doubled by decreasing expression of a single transcriptional regulator. Nature Biotech. 35, 647, doi:10.1038/nbt.3865 (2017).

101 De Beenhouwer, M., Aerts, R. \& Honnay, O. A global meta-analysis of the biodiversity and ecosystem service benefits of coffee and cacao agroforestry. Agric. Ecosyst. Env. 175, 1-7, doi:10.1016/j.agee.2013.05.003 (2013).

102 Strassburg, B. B. N. et al. Global priority areas for ecosystem restoration. Nature, doi:10.1038/s41586-020-2784-9 (2020).

103 Payán, E. \& Boron, V. The Future of Wild Mammals in Oil Palm Landscapes in the Neotropics. Front. Forests Glob. Change 2, doi:10.3389/ffgc.2019.00061 (2019).

104 Maddox, T., Priatna, D., Gemita, E. \& Salampessy, A. The conservation of tigers and other wildlife in oil palm plantations Jambi Province, Sumatra, Indonesia. ZSL Conservation Report No.7. (The Zoological Society of London, London, UK, 2007).

105 Ancrenaz, M. et al. Pongo pygmaeus. IUCN Red List Threat. Sp., e.T17975A17966347 (2016). 
106 Pangau-Adam, M., Mühlenberg, M. \& Waltert, M. Rainforest disturbance affects population density of the northern cassowary Casuarius unappendiculatus in Papua, Indonesia. Oryx 49, 735-742, doi:10.1017/S0030605313001464 (2014).

107 Alamgir, M. et al. Infrastructure expansion challenges sustainable development in Papua New Guinea. PLOS ONE 14, e0219408, doi:10.1371/journal.pone.0219408 (2019).

108 Katiyar, R. et al. Microalgae: An emerging source of energy based bio-products and a solution for environmental issues. Renew. Sust. Energy Rev. 72, 1083-1093, doi:10.1016/j.rser.2016.10.028 (2017).

109 Nomanbhay, S., Salman, B., Hussain, R. \& Ong, M. Y. Microwave pyrolysis of lignocellulosic biomass - a contribution to power Africa. Energy Sust. Soc. 7, 23, doi:10.1186/s13705-0170126-z (2017).

Correspondence and requests for materials should be addressed to emeijaard@gmail.com.

Acknowledgements The development of this situation analysis was supported by the IUCN project

"Global Commons: Solutions for a Crowded Planet", funded by the Global Environment Facility. DJB

received funding from the UK Research and Innovation's Global Challenges Research Fund under the Trade, Development and the Environment Hub project (project number ES/S008160/1). MP was supported by the CNPq research productivity fellowships (\#308403/2017-7). JGU was funded by SNSF R4D-project Oil Palm Adaptive Landscapes.

\section{Author contributions}

EM, DS, and TB conceptualized this study and developed the initial manuscript, with KC, JGU, DG, JSHL, DJB, SAW, MA, SW, LPK, JFA, ZS and AD assisting in the acquisition, analysis, and interpretation of the data and further writing. ES, TS, JA, HP, CS, DM, PF, NM, RH, MP, and MS provided substantial input into the text revisions, and NZ, JA, DJB, KC, DG, AD and JFA designed the graphics.

\section{Competing Interests statement}

None of co-authors in this study, except DJB, MP, and JGU, received funding for conducting this review, although the information was partly based on a study funded by the Global Environment 
672 Facility. EM, TB, DG, MA, SW, LPK, JGU, KC, NM and DS are members of and have received funding

673 from the IUCN Oil Palm Task Force, a group tasked by the IUCN members to investigate the

674 sustainability of palm oil. TB, DJB, MA, CS and NM work for conservation organizations and EM, MA

675 and MP have done work paid by palm oil companies or the Roundtable on Sustainable Palm Oil. 
676

FIGURE LEGENDS

677

678

679

680

681

Figure 1. Main vegetable oil crops (see Table 1). (a) Harvested area from 1961 to 2017. (b)

Vegetable oil production from 1961 to 2014. Data from FAOSTAT ${ }^{4}$.

Figure 2. Maps of industrial and smallholder-scale oil palm from analysis of satellite imagery until the second half of $2019^{3}$, and examples of species it affects negatively: (a) Panthera onca (Near Threatened) ${ }^{103}$ and Ara macao (Least Concern) ${ }^{39}$; (b) Pan troglodytes (Endangered) ${ }^{80}$; (c) Panthera tigris (Endangered) ${ }^{104}$, Helarctos malayanus (Vulnerable) ${ }^{104}$, Pongo pygmaeus (Critically Endangered $)^{105}$, Casuarius unappendiculatus (Least Concern) ${ }^{106}$, and Dendrolagus goodfellowi (Endangered $)^{107}$. The maps lack information on plantations $<3$ years old and planted oil palm in mixed agroforestry settings, but provide the most up-to-date estimates available. For each region the percentages of intact (green) and non-intact forests (orange) are shown relative to the total extent of forest ecosystems ${ }^{22}$.

Figure 3. Oil palm's estimated role in deforestation aggregated across studies, years, and regions. Panel a depicts the contribution of oil palm to overall deforestation, while $b$ shows the percentage of all oil palm expansion that cleared forest (Supplementary Methods). There were no data for Peru and South and Central America for panel a, and no global data for panel b. Southeast Asia (SE Asia) excludes Indonesia and Malaysia, which are shown separately, while South America excludes Peru. Each filled circle represents one time period from a single study, with individual studies represented by distinct colours. The size of the circle corresponds to the relative number of areayears represented in that time period (larger circles represent a larger study area and longer time period of sampling). Boxplot middle bars correspond to the unweighted median across study-time 
periods; lower and upper hinges represent the $25^{\text {th }}$ and $75^{\text {th }}$ percentiles of study-time periods; and

701 whiskers extend from the upper (lower) hinge to the largest (smallest) value no further than 1.5

702 times the interquartile range from the hinge (Figure S2, Tables S2 and S3).

703

Figure 4 - Species groups with more than 8 threatened species with the terms "palm oil" or "oil palm" in the threats texts of the IUCN Red List of Threatened Species Assessments ${ }^{29}$. In total 321 species assessments had oil palm plantations as one of the reported threats (301 when excluding groups with $<8$ threatened species), which constitutes $3.5 \%$ of threatened species threatened by annual and perennial non-timber crops (9,088 species) and $1.2 \%$ of all globally threatened species (27,159 species) in 2019 (Supplementary Material and Table S4). CR = Critically Endangered; EN = Endangered; VU = Vulnerable .

711

712

713 
Table 1. Overview of the major oil crops, typical production cycle, yields, main production

countries, biomes in which impacts primarily occur, carbon emissions, the number of threatened species according to the IUCN Red List of Threatened Species ${ }^{29}$ for which the specific crop is

mentioned as a threat, and the median species richness and median range-size rarity (amphibians,

birds and mammals) of species occurring within the footprint of each crop with first and third

quartile in brackets (IUCN Red List) (see Supporting Online Methods, Figure S1, Table S4). Carbon data are available.

\begin{tabular}{|c|c|c|c|c|c|c|c|c|}
\hline Oil crop & Type of crop & $\begin{array}{l}\text { Oil yield } \\
\text { (t ha-1) } \\
108,109\end{array}$ & $\begin{array}{l}\text { Main oil } \\
\text { production } \\
\text { countries }\end{array}$ & $\begin{array}{l}\text { Main biome } \\
\text { impacted }\end{array}$ & $\begin{array}{l}\mathrm{Kg} \\
\mathrm{CO} 2 \mathrm{e} / \mathrm{MJ} \\
61\end{array}$ & $\begin{array}{l}\text { \# species } \\
\text { threatened } \\
\text { by crop }\end{array}$ & $\begin{array}{l}\text { Median } \\
\text { Species } \\
\text { Richness } \\
\text { (number } \\
\text { of } \\
\text { species) } 29\end{array}$ & $\begin{array}{l}\text { Median } \\
\text { range-size } \\
\text { rarity (ha } \\
\text { ha }^{-1} \\
10 \mathrm{e} 5)^{29}\end{array}$ \\
\hline $\begin{array}{l}\text { Oil palm } \\
\text { Elaeis } \\
\text { guineensis }\end{array}$ & $\begin{array}{l}\text { Perennial ( } 25 \\
\text { years cycle) }\end{array}$ & $1.9-4.8$ & $\begin{array}{l}\text { Indonesia, } \\
\text { Malaysia, } \\
\text { Thailand }\end{array}$ & Tropical rainforest & 1.2 & 321 & $\begin{array}{l}472[443, \\
504]\end{array}$ & $\begin{array}{l}36[27, \\
57]\end{array}$ \\
\hline $\begin{array}{l}\text { Soybean } \\
\text { Glycine max }\end{array}$ & $\begin{array}{l}\text { Annual ( 6 } \\
\text { months } \\
\text { cycle), } \\
\text { rotated with } \\
\text { other crops }\end{array}$ & $0.4-0.8$ & $\begin{array}{l}\text { China, USA, } \\
\text { Brazil, } \\
\text { Argentina }\end{array}$ & $\begin{array}{l}\text { Subtropical grass } \\
\text { savanna, } \\
\text { temperate steppe, } \\
\text { and broadleaf } \\
\text { forest }\end{array}$ & 1.3 & 73 & $\begin{array}{l}278[251, \\
462]\end{array}$ & $10[5,14]$ \\
\hline $\begin{array}{l}\text { Rapeseed } \\
\text { Brassica } \\
\text { napus and } \\
\text { B. } \\
\text { Campestris }\end{array}$ & $\begin{array}{l}\text { Annual ( 6 } \\
\text { months } \\
\text { cycle). } \\
\text { Rotated with } \\
\text { other crops }\end{array}$ & $0.7-1.8$ & $\begin{array}{l}\text { China, } \\
\text { Germany, } \\
\text { Canada }\end{array}$ & $\begin{array}{l}\text { Temperate steppe } \\
\text { and broadleaf } \\
\text { forest and taiga }\end{array}$ & 1.2 & 1 & $\begin{array}{l}227[187, \\
308]\end{array}$ & $4[3,10]$ \\
\hline $\begin{array}{l}\text { Cotton } \\
\text { Gossypium } \\
\text { hirsutum }\end{array}$ & $\begin{array}{l}\text { Annual ( } 6 \\
\text { months } \\
\text { cycle). } \\
\text { Rotated with } \\
\text { other crops }\end{array}$ & $0.3-0.4$ & $\begin{array}{l}\text { China, } \\
\text { India }\end{array}$ & $\begin{array}{l}\text { Subtropical } \\
\text { monsoon, dry and } \\
\text { humid forest and } \\
\text { temperate areas }\end{array}$ & 1.2 & 35 & $\begin{array}{l}299[234, \\
347]\end{array}$ & $10[7,12]$ \\
\hline $\begin{array}{l}\text { Groundnuts } \\
\text { or peanuts } \\
\text { Arachis }\end{array}$ & $\begin{array}{l}\text { Annual (4-5 } \\
\text { months crop } \\
\text { cycle). }\end{array}$ & $0.5-0.8$ & $\begin{array}{l}\text { China, } \\
\text { India }\end{array}$ & $\begin{array}{l}\text { Subtropical } \\
\text { monsoon, dry and } \\
\text { humid forest and }\end{array}$ & 1.5 & 6 & $\begin{array}{l}351[308, \\
426]\end{array}$ & $11[7,16]$ \\
\hline
\end{tabular}




\begin{tabular}{|c|c|c|c|c|c|c|c|c|}
\hline hypogaea & $\begin{array}{l}\text { Rotated with } \\
\text { other crops }\end{array}$ & & & temperate areas & & & & \\
\hline $\begin{array}{l}\text { Sunflower } \\
\text { Helianthus } \\
\text { annuus }\end{array}$ & $\begin{array}{l}\text { Annual (3-4 } \\
\text { months crop } \\
\text { cycle). } \\
\text { Rotated with } \\
\text { other crops }\end{array}$ & $0.5-0.9$ & $\begin{array}{l}\text { Ukraine, } \\
\text { Russia }\end{array}$ & $\begin{array}{l}\text { Temperate steppe } \\
\text { and broadleaf } \\
\text { forest }\end{array}$ & 1.0 & 1 & $\begin{array}{l}189[177, \\
222]\end{array}$ & $3[2,9]$ \\
\hline $\begin{array}{l}\text { Coconut } \\
\text { Cocos } \\
\text { nucifera }\end{array}$ & $\begin{array}{l}\text { Perennial ( } 30 \\
-50 \text { y cycle) }\end{array}$ & $0.4-2.4$ & $\begin{array}{l}\text { Philippines, } \\
\text { Indonesia, } \\
\text { India }\end{array}$ & $\begin{array}{l}\text { Tropical and } \\
\text { subtropical forest }\end{array}$ & $n / a$ & 65 & $\begin{array}{l}317[264, \\
414]\end{array}$ & $\begin{array}{l}73[35, \\
113]\end{array}$ \\
\hline $\begin{array}{l}\text { Maize } \\
\text { Zea mays }\end{array}$ & $\begin{array}{l}\text { Annual (5-6 } \\
\text { months crop } \\
\text { cycle). } \\
\text { Rotated with } \\
\text { other crops }\end{array}$ & $0.1-0.2$ & USA, China, & $\begin{array}{l}\text { Temperate steppe } \\
\text { and broadleaf } \\
\text { forest }\end{array}$ & 0.7 & 131 & $\begin{array}{l}273[222, \\
427]\end{array}$ & $9[5,20]$ \\
\hline $\begin{array}{l}\text { Olive } \\
\text { Olea } \\
\text { europaea }\end{array}$ & $\begin{array}{l}\text { Perennial, } \\
\text { long lived. } \\
\text { Sometimes } \\
\text { inter-cropped }\end{array}$ & $0.3-2.9$ & $\begin{array}{l}\text { Spain, Italy, } \\
\text { Greece }\end{array}$ & $\begin{array}{l}\text { Mediterranean } \\
\text { vegetation }\end{array}$ & $n / a$ & 14 & $n / a$ & $\mathrm{n} / \mathrm{a}$ \\
\hline
\end{tabular}

722 
$\begin{array}{llllllllllll}1960 & 1965 & 1970 & 1975 & 1980 & 1985 & 1990 & 1995 & 2000 & 2005 & 2010 & 2015\end{array}$ Year

b

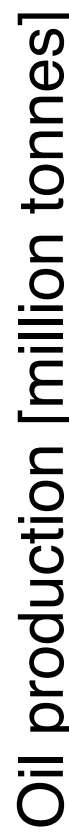

0

$\begin{array}{llllllllllll}1960 & 1965 & 1970 & 1975 & 1980 & 1985 & 1990 & 1995 & 2000 & 2005 & 2010 & 2015\end{array}$ Year

$$
\begin{aligned}
& - \text { Coconut }- \text { Olive } \\
\text { Oil crop } & - \text { Maize }- \text { Rapeseed } \\
& - \text { Oil palm }- \text { Soybean }
\end{aligned}
$$


South America -

West Africa

West Africa -

SE Asia

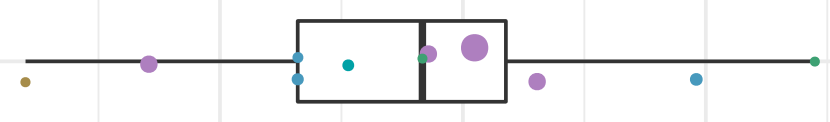

Peru -

Indonesia
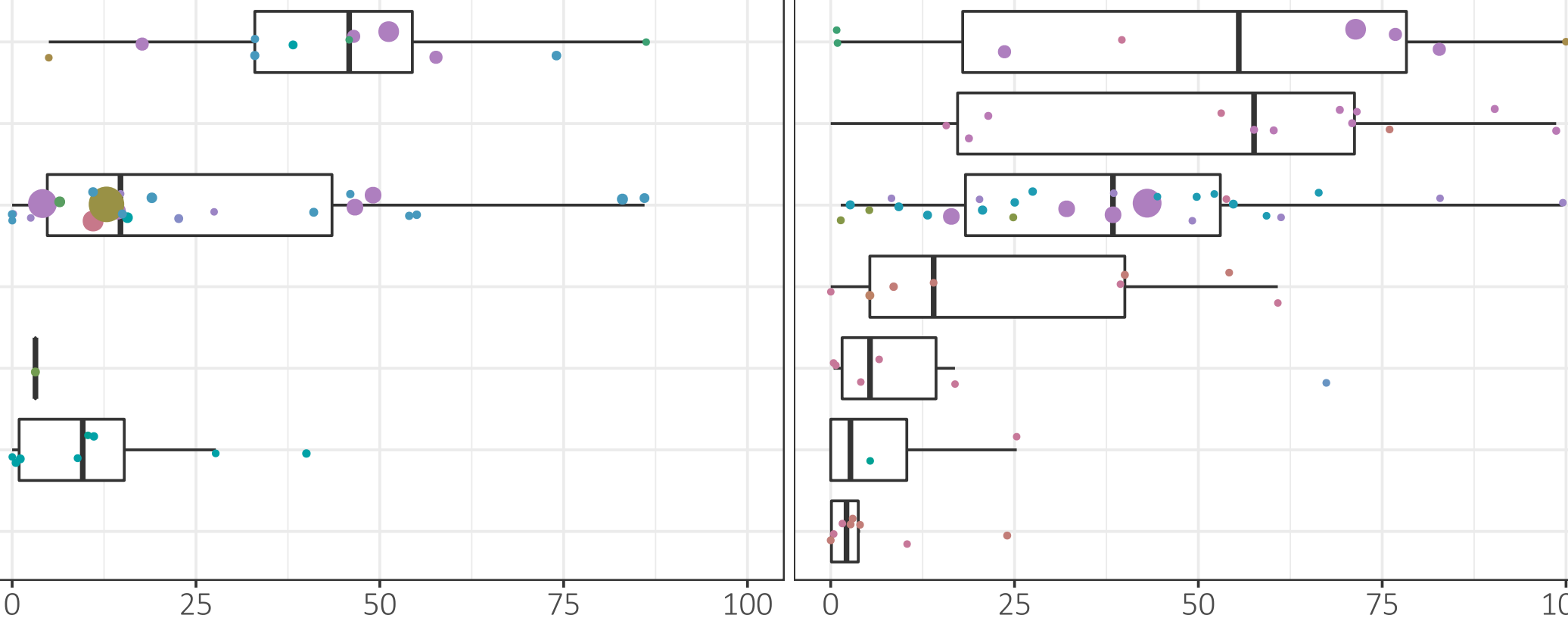

$-10$

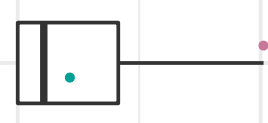

罚。

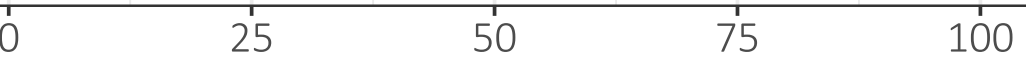

Percent of oil palm expansion into forest 


\section{\begin{tabular}{ll|l|l} 
Reptiles & 1 & 6 & 4
\end{tabular}}

Amphibians

\section{Freshwater fish}

Birds
Mammals
Plants

\begin{tabular}{l|l|l}
2 & 11 & 10
\end{tabular}
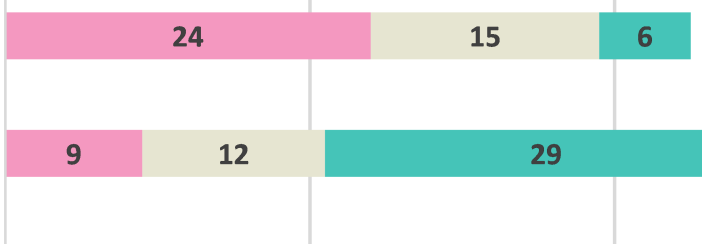

0 